\title{
PRODUCTIVE PERFORMANCE AND BLOOD PLASMA CONSTITUENTS OF BROILER CHICKS FED DIETS SUPPLEMENTED WITH SOME NATURAL FEED ADDITIVES
}

\author{
A.I. El-Faham ${ }^{1}$, Nematallah G.M. Ali ${ }^{1}$ and Amal M. Hassan ${ }^{2}$ \\ ${ }^{1}$ Poult. Prod. Dept., Fac. of Agric., Ain Shams Univ., Egypt. \\ ${ }^{2}$ Animal and Poult. Physiol. Dept., Desert Research Center, Mataria, Egypt.
}

\section{SUMMARY}

\begin{abstract}
A grower broiler experiment (from 1 to 5 weeks of age) was conducted to study the impact of various commercial feed additives on performance and economical efficiency of broiler chicks. These additives included commercial premixture of flavouring substance (Biostrong® 510), commercial enzyme preparation (Nutrikem dry ${ }^{\circledR}$ and symbiotic (Bio-gen $\left.{ }^{\circledR}\right)$. A number of 120 Hubbard broiler chicks (1 week of age) were divided into 4 treatment groups (3 replicates of 10 chicks, each). Groups were assigned to 4 experimental diets: a basal diet of no additive (control), the basal diet supplemented with either $150 \mathrm{~g} /$ ton Biostrong $\left(\mathrm{T}_{1}\right)$, $500 \mathrm{~g} /$ ton Nutrikem dry $\left(\mathrm{T}_{2}\right)$ or $500 \mathrm{~g} /$ ton Bio-gen $\left(\mathrm{T}_{3}\right)$.

The results indicated that:

1- Supplementation of Biostrong or Nutrikem recorded insignificant higher body weight gain by (8 and 3\%, respectively) than the control or Bio-gen groups.

2- Supplementation of Bio-gen recorded significant $(\mathrm{P}<0.05)$ higher feed intake and worst feed conversion (1.81) than those fed other dietary treatments, but numerically Biostrong and Nutrikem treatments $\left(\mathrm{T}_{1}\right.$ and $\mathrm{T}_{2}$ ) represented the best feed conversion (being the same figure $1.54 \mathrm{~g}$ ) compared with that fed control diet (1.65).

3- Carcass characteristics parameters (dressing, giblets and abdominal fat \%) and carcass parts \% (breast, thigh, drumstick and wing \%) showed insignificant figures when chicks fed different dietary treatments.

4- Bone measurements (wet tibia weight and tibia width) showed insignificant figures, however tibia length and tibia Seedor index have significant differences for dietary treatments.

5- Biostrong $\left(\mathrm{T}_{1}\right)$ and symbiotic $\left(\mathrm{T}_{3}\right)$ significantly improved the total protein, and globulin values compared with $\mathrm{T}_{2}$ group. However the $\mathrm{T}_{3}$ treatment and control have the best $\mathrm{A} / \mathrm{G}$ ratio.

6- Enzyme treatment (Nutrikem, $\mathrm{T}_{2}$ ) decreased plasma triglycerides cholesterol and LDL concentrations compared with other treatments $\left(\mathrm{T}_{1}\right.$ and $\left.\mathrm{T}_{3}\right)$.

7- Concerning economic evaluation, the best economical efficiency value was demonstrated when broiler chicks fed $150 \mathrm{~g} /$ ton Biostrong $\left(\mathrm{T}_{1}\right)$ and the value was $21 \%$ more when compared with that of broiler chicks fed control diet.

It could be concluded that supplementation basal diets with $150 \mathrm{~g} /$ ton Biostrong improved productive performance and enhanced economic efficiency of Hubbard broiler chicks.
\end{abstract}

Keywords: Biostrong, symbiotic, enzyme preparation and broiler chicks.

\section{INTRODUCTION}

Growth promoters are substances that are added to a nutritionally balanced diet to provoke response towards the exploitation of maximum genetic potential of the host, in terms of growth as well as improvement in feed conversion efficiency. There are different types of growth promoters which are used to exploit the broiler industry like antibiotics, probiotics, prebiotics, symbiotic, (probiotic plus prebiotic), exogenous enzymes, Aromatic plants, herbs or products including plant extracts, essential oils or the main components of the essential oil and certain other nutritional substances (Dhama et al., 2007, 2008, 2011; Mahima et al., 2012, 2013 and El-Faham et al., 2014, 2015).

Antibiotics are given at subtherapeutic dosage for stabilization of the microflora of intestine and for improving the performance in general along with prevention of certain specific pathological conditions of the intestine. However, when using antibiotics as growth promoters it should be kept in mind that theifor on long term basis must be avoided as it can give rise to resistance groups of microorganisms viz, gram negative bacteria (E. coli and Slamonella spp.) (Dibner and Richards, 2005; HasRsanet al., 2010 and 


\section{El-Faham et al.}

Senjya et al., 2012). Therefore, many countries tended to prohibit the using of antibiotics as growth promoters because of their side effect on both birds and human health (European commission, 2003).

As a result, the natural additives such as spices, herbs and their extracts are given to birds to improve their physiological and productive performance under normal or stress conditions (Tollba et al., 2004 a,b).

Biostrong® is a plant derived (phytogenic), feed additive for poultry. It is comprised of high quality proven active ingredients that improve digestion, enhance metabolic function and increase nutrient retention. So, Biostrong optimizes performance, production and profitability (Lee et al., 2004 and ElFaham et al., 2014). The active ingredients of biostrong are essential oils, bitter substances, pungent substances and saponins derived from herbs, spices and their extracts.

Numerous studies demonstrated that, a great number of medical and aromatic herbs as well as essential oils and pungent substances are used as natural growth promoters in broilers (Tollba and Hassan, 2003) in ducks (Gazalah and Ibrahim, 1996) and in Japanese quail (Abd El-Azeem et al., 2001).

Supplemental direct fed microbial has received special attention from the broilers industry to promote the balance and quality of the intestinal microflora for the host, but the efficacy of these products varies according to their production procedure and practical application (Salim et al., 2013). Moreover, probiotics can improve the metabolism of the host bird in various ways including absorptive capacity, protein metabolism, energy metabolism, fiber digestion and gut maturation (Yokota and Coates, 1982; Salter et al., 1974; Muramatsu et al., 1994; Furuse and Yokota, 1984; and Furuse et al., 1991 and Dhama and Singh, 2010). Several researchers reported that feeding symbiotic products (probiotic plus prebiotic) had improved the growth performance of broiler chickens (Mohnalet al., 2007 and Nematallah et al., 2015).

The application of exogenous enzymes in poultry nutrition has been driven by accruing benefits in terms of improved dietary nutrient utilization and growth performance (Hong et al., 2002 and Adeola and Bedford, 2004).

The improvements in growth of broilers fed a diet with enzymes supplementation may be interpreted based on eliminate the effects of ant nutritional factors (Yu et al., 2007), improve the utilization of dietary energy (Kocher et al., 2003), improve the utilization of protein (Abd El-Hady, 2012), prevents exponential multiplication of common pathogenic bacteria (Hillman, 1999). This is reflected in better flock performance, better litter quality and improved bird health, which in turn has a positive influence on total production costs (Saleh et al., 2005).

Therefore, the aim of the present trial was tostudy the effects of commercial enzyme preparation (Nutrikem dry®), Symbiotic (Bio-gen $®$ ) in comparing with (Biostrong-510®) incorporation in broiler diets on growth performance, carcass characteristics, blood plasma parameters and economic efficiency.

\section{MATERIALS AND METHODS}

The trial was conducted at Poultry Experimental Unit, Agriculture Experiment and Research Station at Shalakan, Faculty of Agriculture, Ain Shams University, in order to investigate growth performance, some blood components, carcass characteristics and economic efficiency of broiler chicks fed all-plant protein diets supplemented with either $0,150 \mathrm{~g} /$ ton (Biostrong ${ }^{\circledR} 510$ ), a commercial premixture of flavouring substance, $500 \mathrm{~g} / \mathrm{ton}$ (Nutrikem dry®) -a commercial enzyme preparation or $500 \mathrm{~g} / \mathrm{ton}$ symbiotic (Bio-gen $\left.{ }^{\circledR}\right)$.

A total of 120 Hubbard broiler chicks (mixed sex) at one day old with an initial body weight (BW) of $44.0 \mathrm{~g}$ were obtained from a local commercial hatchery and used in this trial. Chicks were fed starter diet $(23 \% \mathrm{CP}$ and $3000 / \mathrm{kcal} \mathrm{ME} / \mathrm{kg}$ ) for the first week of age and then randomly distributed into 4 starter dietary treatments (2-3 weeks) and grower diets (21CP and $3100 \mathrm{kcal} \mathrm{ME} / \mathrm{kg}$ ) until the end of the experimental period ( 5 weeks).

Biostrong ${ }^{\circledR}$ is a plant derived; feed additive for poultry and the active ingredients are essential oils, bitter substances, pungent substances and saponins derived from herbs, spices and their extracts. Nutrikem dry ${ }^{\circledR}$ contains a mix of exogenous enzyme (Xylanase, cellulose and Betaglucanase) and endogenous enzyme (Alpha amylase and protease), all enzyme inarched on matrix of lysophosphatydial choline.

Bio-gen ${ }^{\circledR}$ is considered as symbiotic contains the following ingredients: Bacillus subtillus $\left(4\right.$ x $10^{12}$ CFU) $200 \mathrm{mg}$ - yeast cell wall extracts of saccharomyces cervisiae (Beta-glucan + MOS).

Chicks were randomly divided into 4 equal groups, each was subdivided into 3 replicates with 10 chicks each. Chicks were housed randomly into battery brooders to 4 dietary treatments from 2 to 5 weeks, under similar conditions and disease control. As shown in Table (1), the experimental diets were 
based on corn-soy diets and formulated to meet the nutrient requirements of broiler chicks according to NRC (1994). The BW and feed consumption were recorded by replicate weekly and mortality was recorded daily. From these data BWG, average daily feed intake (DFI), FCR corrected for mortality and mortality rates were calculated cumulatively.

At the end of the trial ( 5 weeks of age), 3 chicks per each treatment were randomly chosen, weighed, slaughtered and eviscerated. Carcass, heart, liver, gizzard, and abdominal fat were weighed and relative weights to live $\mathrm{BW}(\mathrm{g} / 100 \mathrm{~g}$ of $\mathrm{BW}$ ) were calculated. Carcass parts $\%$ were evaluated using breast, thigh, drumstick and wing weights and percentages were calculated in relation to carcass weight.

Bone quality measurements were evaluated using wet and dry tibia weight, tibia length and weight and tibia seedor index (SI) using the following equation suggested by Seedor et al. (1991). [SI = Tibia dry weight $(\mathrm{g}) /$ tibia length $(\mathrm{cm})]$.Blood samples were collected in dry clean centrifuge tubes from the slaughtered birds and plasma were separated by centrifugation at $3000(\mathrm{rpm})$ for 15 minutes. Clear plasma samples were separated into Ependorph tubes and kept in the deep freezer at $-20^{\circ} \mathrm{c}$ until chemical analysis. Values of total protein, albumin, triglyceride, total cholesterol, low density lipoprotein (LDL) and high density lipoprotein (HDL) were estimated by using commercial diagnosing kits (produced by Biodiagnostic company, Egypt), the globulin values were obtained by subtracting the values of albumin from the corresponding values of total protein.

Economic parameters of production including feeding cost (starter and grower diets) income and returns per bird were calculated. Economic efficiency was calculated as net return / total cost and relative economic efficiency assuming control treatment $100 \%$.

Data were statistically analyzed by analysis of variance (ANOVA) one-way using the General Linear Model (GLM) procedure of SAS (2004). Means were compared using Duncan's Multiple Range Test (Duncan, 1955) where the level of significance set at minimum $(\mathrm{P} \leq 0.05)$.

\section{RESULTS AND DISCUSSION}

Table (2) shows the effect of dietary treatments on the productive performance [body weight gain (BWG), feed intake (FI) and feed conversion ratio (FCR) during starter, grower and overall experimental period]. The results of BWG showed that birds fed biostrong supplemented diet $\left(\mathrm{T}_{1}\right)$ exhibited significantly $(\mathrm{P}<0.05)$ higher BWG during the period $(4-5$ weeks $)$ and insignificant higher during starter period (2-3 weeks) and overall experimental period (2-5 weeks) increased gain compared with control group.

At 5 weeks of age, birds fed the Biostrong $\left(T_{1}\right)$ or enzyme preparation $\left(T_{2}\right)$ supplemented diets recorded 8 and $3 \%$ more gain, respectively than the control or Bio-gen $\left(\mathrm{T}_{3}\right)$ groups. The differences among treatments were not significant. Feed intake and feed conversion ratio were significantly different among treatments during studied period (1-5 weeks). Moreover, during starter, grower and the entire period birds fed Bio-gen supplemented diet $\left(\mathrm{T}_{3}\right)$ consumed significantly $(\mathrm{P}<0.05)$ more feed than the other groups. No significant differences were detected on FI between control group and those fed Biostrong $\left(T_{1}\right)$ or Nutrikem dry $\left(T_{2}\right)$ supplemented diets during the periods from 4-5 or 2-5 weeks of age.

The results of FCR showed that, no significant differences were detected between the control group and those fed Biostrong $\left(\mathrm{T}_{1}\right)$ or Nutrikem dry $\left(\mathrm{T}_{2}\right)$ supplemented diets during growing and the entired period. Moreover, feeding $\mathrm{T}_{1}$ or $\mathrm{T}_{2}$ diets gave the best FCR [being the same figure (1.54)] compared with control group (1.65).

On the other hand, the worst FCR was found in birds fed Bio-gen supplemented diet $\left(\mathrm{T}_{3}\right)$ being (1.81),besides, the differences between treatments were significant and this reduction may be due to the high feed intake during experimental period (1-5 weeks of age). These results indicated the superiority of Biostrong compared to Nutrikem or Bio-gen and addition of either Biostrong or Nutrikem improved the performance of growing broilers expressed as BWG or FCR. Chicks fed such supplemented diets utilized feed more efficient than the control group.

The results of the present study confirmed those obtained by El-Faham et al. (2014), Al-Khdri (2013) and Rahimi et al. (2011) who concluded that higher body weight are noted in the broilers fed herbs and herbal products. These productsare incorporated in poultry diet to replace synthetic products in order to stimulate or promote the effective use of feed nutrients which may subsequently result in more rapid body weight gain, higher production rates and improved feed efficiency.

Moreover, supplementation of spices and herbs could have many benefits to broilers health and performance such as having antioxidative potential, antimicrobial activity and substances enhancing digestion by stimulating endogenous enzymes (Dorman and Deans, 2000; Lee et al., 2004; Ghazalah and Ali, 2008; Steiner, 2009 and Al-Khadri, 2013). 


\section{El-Faham et al.}

Moreover, these results are in agreement with several reports regarding enzyme addition in broiler corn-SBM basal diets (Salah et al., 2005; Kalmendal and Tauson, 2012; and Safaa, 2013), who reported that supplementing corn-SBM based broiler diets with an enzyme product containing xylanase, amylase and protease improved body weight gain and feed efficiency compared with the supplemented diets.

\section{Carcass characteristics:}

Table (3) shows the effect of different dietary treatments on carcass characteristics for the chicks slaughtered at the end of 5 weeks of age. Experimental treatments $\left(\mathrm{T}_{1-3}\right)$ had no significant effect on studied parameters compared with control, except liver percentages. The corresponding values for dressing percentages ranged between 72.69 and $74.69 \%$, while giblets percentages ranged between 3.11 and $4.19 \%$ and abdominal fat percentages ranged between 1.59 and $1.84 \%$, however, the differences between treatments were insignificant.

Moreover, it is worth to note that broiler chicken fed diet supplemented with Bio-gen $\left(\mathrm{T}_{3}\right)$ during experimental period ( 5 weeks) reflected the highest, insignificant dressing, giblets, abdominal fat and significant liver percentages compared with those fed other dietary treatments.

These findings are in contrast with the results obtained by Hassan et al. (2004), who concluded that addition of medicinal and aromatic plants in broiler diets had significantly higher dressing $\%$ than those fed the control diet. Also, results are disagreement with café' et al. (2002), who noted a significant increase in dressing percentage at 42 days of age in broilers given a corn-SBM diet supplemented with commercial enzymes. Conversely, Ali (1999) detected that there were no significant differences in absolute and relative weights of empty carcass, total giblets, abdominal fat and total edible parts between the control group and the birds fed diets containing probiotics.

\section{Carcass parts (\%):}

The results in Table (4) shows the relationship between dietary treatments and carcass parts of broiler chicks slaughtered at the end of the experiment ( 5 weeks of age). No significant differences in all carcass parts percentages (breast, thigh, drumstick and wing \%) were obtained due to experimental treatments, but there was significant increase in breast muscle $\%$ and pectoralis major $\%$ by feeding Biostrong diet $\left(\mathrm{T}_{1}\right)$ compared with those fed control diet, the corresponding figures were (29.15 and 23.07 vs 24.45 and $19.25 \%$, respectively).

\section{Bone measurements:}

Dietary treatments had a significant effect upon some of tibia bone traits included in this study as shown in Table (5). Tibia length $(\mathrm{mm})$ ranged between 9.16 and $8.46(\mathrm{~mm})$ and chicks fed diet supplemented withBiostrong $\left(\mathrm{T}_{1}\right)$ gave the highest figure while, birds fed Nutrikem supplemented diet $\left(\mathrm{T}_{2}\right)$ had the lowest figures $(8.46 \mathrm{~mm})$ and differences among treatments were significant. In the same side, Tibia Seedor Index (SI), wet tibia weight (g) and percentage of tibia weight in relation to body weight for chicks fed Nutrikem supplemented diet $\left(\mathrm{T}_{2}\right)$ reflected the highest figures than those fed Biogen diet $\left(\mathrm{T}_{3}\right)$. The corresponding values for Seedor Index ranged between 0.56 and 0.69 and wet tibia ranged between 0.56 and 0.69 and wet tibia weight ranged between 10.07 and 12.37, while tibia weight \% ranged between 0.45 and $0.57 \%$ and in most cases differences between treatments were insignificant.

These findings are in contrast to the results of (El-Faham et al., 2014) who found that diet supplemented with probiotic, Biostrong, Pungent substance or Zinc bacitracin had no significant effect on different bone measurements. Ziaie et al. (2011) indicated that supplementation broiler diet with antibiotic and its alternative such as prebiotic, probiotic, commercial herbal blend and organic acid could improve bone characteristics.

\section{Effect of experimental treatments on some blood parameters of growing chicks:}

Table (6) shows the effect of different treatments on some blood components of growing chicks. Generally, some blood components have significantly affected by different treatments and others have not significantly affected $(\mathrm{P} \leq 0.05)$.

Total protein, albumin, globulin and triglycerides have been significantly affected. Biostrong $\left(\mathrm{T}_{1}\right)$ and symbiotic $\left(\mathrm{T}_{3}\right)$ have improved the total protein, albumin and globulin values compared with control, although $\mathrm{A} / \mathrm{G}$ ratio recorded the best values for birds that treated with $\mathrm{T} 3$, and control but the differences have failed to reach in significances.

Concerning to plasma lipids, birds that fed on Nutrikem $\left(\mathrm{T}_{2}\right)$ showed the lowest values for triglycerides, cholesterol and LDL compared to other treatments $\left(\mathrm{T}_{1}\right.$ and $\left.\mathrm{T}_{3}\right)$. However the control group recorded the lowest levels of total cholesterol, $\mathrm{LDL}$ and HDL compared to other treatments $\left(\mathrm{T}_{1-3}\right)$

From the previous results it could be concluded that Biostrong, Nutrikem and Bio-gen supplements have improved the general productive performance of broiler chicks in terms of LBW and FCR. 
Alvarega et al. (2011) and Hermier (1997) reviewed that growth of adipose tissue depends mainly on triacylglycerol transported by LDLs and this could alter the metabolism of lipoprotein on three levels: liver, plasma and adipose tissue.

These results are in close agreement to results of (Nematallah et al., 2014), who mentioned that Biostrong and other feed additives may have many types of components that provide unique health benefits by decreasing free radical and increasing the antioxidant capacity these components may be reflected in increased performance and enhance the immune response of birds.

\section{Economical evaluation:}

Data for economic evaluation are summarized in Table (7). The price figures are based on the recent prices of local market for feed ingredients and selling price of chickens in Qaliobeya region, Egypt, during April 2013.

Results in Table (7) showed that, chicks fed diet contained Biostrong $\left(\mathrm{T}_{1}\right)$ or Nitrokem $\left(\mathrm{T}_{2}\right)$ had the best economical and relative efficiency values being (27.4 and 25.9) and (121 and 115\%) respectively (this may be due to total and net revenue / chick and good performance) as compared with control. Whereas, chicks fed diet contained Bio-gen $\left(\mathrm{T}_{3}\right)$ had the lowest corresponding values, being 16.8 and $74.3 \%$, respectively.

Abd El-Latif et al. (2002) reported that, the profitability of adding $0.5 \%$ probiotic recorded the worst value of economic efficiency compared with control group. On the other hand, Hassanein (2006) concluded that symbiotic or probiotic displayed a greater efficiency as growth promoters for broiler and gave the best total net revenue and economic efficiency. It could be recommended from this study to supplement $150 \mathrm{~g} /$ ton of Biostrong ${ }^{\circledR}$ to broiler diets up to 5 weeks of age.

Table (1). Composition and calculated analysis of the basel experimental starter and grower diets.

\begin{tabular}{|c|c|c|}
\hline Ingredients & $\begin{array}{l}\text { Starter diet } \\
(2-3 w k s)\end{array}$ & $\begin{array}{l}\text { Grower diets } \\
(4-5 \mathrm{wks})\end{array}$ \\
\hline Yellow corn & 55.99 & 59.89 \\
\hline Soy bean meal (44\% cp) & 28.79 & 26.29 \\
\hline Corn gluten $(60 \% \mathrm{cp})$ & 8.99 & 7.01 \\
\hline Soy bean oil & 1.50 & 2.50 \\
\hline Limestone & 1.60 & 1.46 \\
\hline Mono caph & 1.85 & 1.64 \\
\hline L-Lysine Hcl & 0.39 & 0.32 \\
\hline Dl-methionine & 0.29 & 0.29 \\
\hline Salt & 0.30 & 0.30 \\
\hline Premix ${ }^{*}$ & 0.30 & 0.30 \\
\hline Total & 100.00 & 100.00 \\
\hline \multicolumn{3}{|l|}{ Calculated analysis } \\
\hline Crude protein $\%$ & 23.00 & 21.00 \\
\hline $\mathrm{ME}(\mathrm{Kcal} / \mathrm{kg})$ & 3000 & 3100 \\
\hline Calcium \% & 1.00 & 0.91 \\
\hline Av. Phosphorus \% & 0.51 & 0.46 \\
\hline Meth. \% & 0.66 & 0.62 \\
\hline Meth. + cyst. \% & 1.05 & 0.98 \\
\hline Lys. \% & 1.40 & 1.62 \\
\hline
\end{tabular}


Table (2). Effect of dietary treatments on growth performance of broiler chicks.

\begin{tabular}{|c|c|c|c|c|c|}
\hline \multirow{2}{*}{ Items } & \multicolumn{4}{|c|}{ Dietary treatments } & \multirow{2}{*}{$\begin{array}{c}\text { Sig. of } \\
\text { Differences }\end{array}$} \\
\hline & Control & $\mathrm{T}_{1}$ & $\mathrm{~T}_{2}$ & $\mathrm{~T}_{3}$ & \\
\hline $\begin{array}{l}\text { Initial body weight } \\
(\mathrm{g}), 1 \mathrm{wk}\end{array}$ & $125.5 \pm 0.87$ & $132.5 \pm 0.87$ & $122.5 \pm 0.29$ & $134.0 \pm 0.58$ & NS \\
\hline \multicolumn{6}{|c|}{ 1-3 wks of age } \\
\hline $\begin{array}{l}\text { Body weight gain } \\
\text { (g) }\end{array}$ & $680 \pm 2.60^{\mathrm{a}}$ & $696 \pm 16.46^{\mathrm{a}}$ & $634.5 \pm 25.12^{\mathrm{b}}$ & $716.5 \pm 3.75^{\mathrm{a}}$ & $*$ \\
\hline Feed Intake (g) & $985.5 \pm 15.88^{\mathrm{a}}$ & $911 \pm 38.11^{b}$ & $949 \pm 34.06^{\mathrm{ab}}$ & $1044.5 \pm 15.88^{a}$ & $*$ \\
\hline $\begin{array}{l}\text { Feed conversion (g } \\
\text { feed / g gain) }\end{array}$ & $1.45 \pm 0.02^{\mathrm{a}}$ & $1.32 \pm 0.08^{\mathrm{b}}$ & $1.50 \pm 0.01^{\mathrm{a}}$ & $1.46 \pm 0.02^{\mathrm{a}}$ & $*$ \\
\hline \multicolumn{6}{|c|}{$4-5$ wks of age } \\
\hline $\begin{array}{l}\text { Body weight gain } \\
\text { (g) }\end{array}$ & $1301 \pm 5.20^{\mathrm{bc}}$ & $1438 \pm 2.02^{\mathrm{a}}$ & $1400.5 \pm 58.02^{\mathrm{ab}}$ & $1265.5 \pm 1.44^{\mathrm{c}}$ & $*$ \\
\hline Feed Intake (g) & $2268 \pm 6.93^{\mathrm{b}}$ & $2371.5 \pm 2.02^{\mathrm{b}}$ & $2173.5 \pm 66.68^{b}$ & $2550 \pm 132.21^{\mathrm{a}}$ & $*$ \\
\hline $\begin{array}{l}\text { Feed conversion (g } \\
\text { feed / g gain) }\end{array}$ & $1.69 \pm 0.06^{\mathrm{b}}$ & $1.65 \pm 0.01^{\mathrm{b}}$ & $1.63 \pm 0.13^{\mathrm{b}}$ & $1.97 \pm 0.12^{\mathrm{a}}$ & $*$ \\
\hline \multicolumn{6}{|c|}{$2-5$ wks of age } \\
\hline $\begin{array}{l}\text { Body weight gain } \\
\text { (g) }\end{array}$ & $\begin{array}{c}1982 \pm 2.6 \\
100\end{array}$ & $\begin{array}{c}2135 \pm 14.43 \\
108\end{array}$ & $\begin{array}{c}2035 \pm 32.91 \\
103\end{array}$ & $\begin{array}{c}1982 \pm 5.20 \\
100\end{array}$ & NS \\
\hline Feed Intake (g) & $\begin{array}{c}3253 \pm 22.81^{\mathrm{b}} \\
100\end{array}$ & $\begin{array}{c}3283 \pm 36.08^{\mathrm{b}} \\
101\end{array}$ & $\begin{array}{c}3123 \pm 100.75^{\mathrm{b}} \\
96\end{array}$ & $\begin{array}{c}3595 \pm 116.34^{\mathrm{a}} \\
111\end{array}$ & $*$ \\
\hline $\begin{array}{l}\text { Feed conversion ( } \mathrm{g} \\
\text { feed / g gain) }\end{array}$ & $\begin{array}{c}1.65 \pm 0.02^{\mathrm{b}} \\
100\end{array}$ & $\begin{array}{c}1.54 \pm 0.03^{\mathrm{b}} \\
93 \\
\end{array}$ & $\begin{array}{c}1.54 \pm 0.08^{\mathrm{b}} \\
93 \\
\end{array}$ & $\begin{array}{c}1.81 \pm 0.06 \\
110\end{array}$ & $*$ \\
\hline
\end{tabular}

Table (3). Effect of different experimental diets on carcass characteristics of broiler chicks.

\begin{tabular}{|c|c|c|c|c|c|}
\hline \multirow{2}{*}{ Items } & \multicolumn{4}{|c|}{ Dietary treatments } & \multirow{2}{*}{$\begin{array}{c}\text { Sig. of } \\
\text { Differences }\end{array}$} \\
\hline & Control & $\mathrm{T}_{1}$ & $\mathrm{~T}_{2}$ & $\mathrm{~T}_{3}$ & \\
\hline $\begin{array}{l}\text { Live body weight } \\
\text { (g) }\end{array}$ & $2182 \pm 128.04$ & $2297.67 \pm 110.63$ & $2102 \pm 114.72$ & $2221 . \pm 116.68$ & NS \\
\hline Carcass weight (g) & $1626.3 \pm 121.84$ & $1701.3 \pm 79.02$ & $1527 \pm 67.0$ & $1644 \pm 96.9$ & NS \\
\hline Dressing \% & $74.57 \pm 1.13$ & $73.26 \pm 1.04$ & $72.69 \pm 0.98$ & $74.69 \pm 0.84$ & NS \\
\hline Liver $\%$ & $2.12 \pm 0.06^{\mathrm{ab}}$ & $1.61 \pm 0.37^{\mathrm{b}}$ & $1.90 \pm 0.23^{\mathrm{ab}}$ & $2.56 \pm 0.37^{\mathrm{a}}$ & $*$ \\
\hline Gizzard \% & $1.11 \pm 0.16$ & $1.02 \pm 0.08$ & $1.31 \pm 0.12$ & $1.14 \pm 0.04$ & NS \\
\hline Heart $\%$ & $0.60 \pm 0.03$ & $0.48 \pm 0.02$ & $0.59 \pm 0.08$ & $0.48 \pm 0.01$ & NS \\
\hline Giblets $\%$ & $3.82 \pm 0.19$ & $3.11 \pm 0.42$ & $3.80 \pm 0.41$ & $4.19 \pm 0.36$ & NS \\
\hline Abdominal fat $\%$ & $1.59 \pm 0.10$ & $1.68 \pm 0.17$ & $1.69 \pm 0.35$ & $1.84 \pm 0.29$ & NS \\
\hline
\end{tabular}

$a, b$ means have different letter(s) in the same raw are significantly different $(P \leq 0.05)$

NS: not significant

Table (4). Effect of different experimental diets on carcass parts (\%) of broiler chicks.

\begin{tabular}{lccccc}
\hline \multirow{2}{*}{ Items } & \multicolumn{4}{c}{ Dietary treatments } & \multirow{2}{*}{$\begin{array}{c}\text { Sig. of } \\
\text { Differences }\end{array}$} \\
\cline { 2 - 5 } & Control & $\mathrm{T}_{1}$ & $\mathrm{~T}_{2}$ & $\mathrm{~T}_{3}$ & $\mathrm{NS}$ \\
Breast & $47.13 \pm 0.16$ & $47.67 \pm 3.78$ & $48.57 \pm 1.43$ & $51.37 \pm 1.47$ & $*$ \\
Breast muscle & $24.45 \pm 2.21^{\mathrm{b}}$ & $29.15 \pm 3.05^{\mathrm{a}}$ & $25.62 \pm 0.45^{\mathrm{b}}$ & $26.25 \pm 1.35^{\mathrm{ab}}$ & $*$ \\
Pectorals major & $19.25 \pm 1.36^{\mathrm{b}}$ & $23.07 \pm 2.68^{\mathrm{a}}$ & $21.18 \pm 0.73^{\mathrm{ab}}$ & $21.3 \pm 1.35^{\mathrm{ab}}$ & $\mathrm{NS}$ \\
Pectorals minor & $5.20 \pm 0.89$ & $6.07 \pm 0.76$ & $4.44 \pm 0.30$ & $4.95 \pm 0.06$ & $\mathrm{NS}$ \\
Thigh & $28.08 \pm 0.71$ & $28.17 \pm 1.57$ & $26.05 \pm 0.94$ & $27.33 \pm 0.39$ & $\mathrm{NS}$ \\
Drumstick & $14.12 \pm 0.75$ & $13.61 \pm 1.18$ & $14.67 \pm 0.29$ & $12.61 \pm 0.99$ & $\mathrm{NS}$ \\
Wing & $11.16 \pm 0.70$ & $10.59 \pm 1.12$ & $10.45 \pm 0.77$ & $8.8 \pm 0.98$ & \\
\hline
\end{tabular}

$a, b$ means have different letter( $s)$ in the same raw are significantly different $(P \leq 0.05)$

NS: not significant. 
Table (5). Effect of different experimental diets on some tibia bone measurements.

\begin{tabular}{lccccc}
\hline \multirow{2}{*}{ Items } & \multicolumn{4}{c}{ Dietary treatments } & \multirow{2}{*}{$\begin{array}{c}\text { Sig. of } \\
\text { Differences }\end{array}$} \\
\cline { 2 - 5 } & Control & $\mathrm{T}_{1}$ & $\mathrm{~T}_{2}$ & $\mathrm{~T}_{3}$ & NS \\
Wet tibia weight $(\mathrm{g})$ & $11.33 \pm 0.03$ & $10.37 \pm 0.04$ & $12.37 \pm 0.03$ & $10.07 \pm 0.01$ & $\mathrm{NS}$ \\
$\%$ & $0.54 \pm 0.06$ & $0.45 \pm 0.02$ & $0.57 \pm 0.03$ & $0.47 \pm 0.01$ & $*$ \\
Tibia length $(\mathrm{mm})$ & $8.66 \pm .0 .24^{\mathrm{ab}}$ & $9.16 \pm 0.14^{\mathrm{a}}$ & $8.46 \pm 0.17^{\mathrm{b}}$ & $8.86 \pm 0.13^{\mathrm{ab}}$ & $\mathrm{NS}$ \\
Tibia width (mm) & $0.65 \pm 0.02$ & $0.70 \pm 0.05$ & $0.63 \pm 0.03$ & $0.70 \pm 0.01$ & $*$ \\
Tibia Seedor Index (SI) & $0.65 \pm 0.03^{\mathrm{ab}}$ & $0.62 \pm 0.02^{\mathrm{ab}}$ & $0.69 \pm 0.03^{\mathrm{a}}$ & $0.56 \pm 0.01 \mathrm{~b}$ & $*$ \\
\hline
\end{tabular}

$a, b$ means have different letter(s) in the same raw are significantly different $(P \leq 0.05)$

NS : not significant

Table (6). Effect of experimental treatments on some blood plasma components of growing chicks.

\begin{tabular}{|c|c|c|c|c|c|}
\hline \multirow{2}{*}{ Items } & \multicolumn{4}{|c|}{ Dietary treatments } & \multirow{2}{*}{ Sig. } \\
\hline & Control & $\mathrm{T}_{1}$ & $\mathrm{~T}_{2}$ & $\mathrm{~T}_{3}$ & \\
\hline Total protein $(\mathrm{g} / \mathrm{dl})$ & $3.36 \pm 0.29^{\mathrm{a}}$ & $4.21 \pm 0.1^{\mathrm{a}}$ & $2.15 \pm 0.35^{b}$ & $3.98 \pm 0.04^{\mathrm{a}}$ & $*$ \\
\hline Albumin $(\mathrm{g} / \mathrm{dl})$ & $1.54 \pm 0.11^{\mathrm{ab}}$ & $2.16 \pm 0.10^{\mathrm{a}}$ & $1.40 \pm 0.32^{\mathrm{b}}$ & $1.65 \pm 0.29^{\mathrm{ab}}$ & $*$ \\
\hline Globulin (g/dl) & $1.82 \pm 0.34^{\mathrm{a}}$ & $2.04 \pm 0.04^{\mathrm{a}}$ & $0.75 \pm 0.07^{\mathrm{b}}$ & $2.34 \pm 0.29^{\mathrm{a}}$ & $*$ \\
\hline $\mathrm{A} / \mathrm{G}$ ratio & $0.96 \pm 0.21$ & $1.06 \pm 0.06$ & $1.86 \pm 0.42$ & $0.76 \pm 0.20$ & NS \\
\hline Triglyceride (g/dl) & $78.24 \pm 5.18^{\mathrm{ab}}$ & $85.29 \pm 10.20^{\mathrm{ab}}$ & $59.12 \pm 12.07^{\mathrm{b}}$ & $112.30 \pm 7.87^{\mathrm{a}}$ & $*$ \\
\hline Total cholesterol (g/dl) & $88.28 \pm 24.40$ & $135.73 \pm 4.25$ & $113.94 \pm 28.62$ & $130.80 \pm 3.48$ & NS \\
\hline $\begin{array}{l}\text { Low density lipoprotein } \\
\text { (g/dl) }\end{array}$ & $67.06 \pm 24.31$ & $108.90 \pm 5.86$ & $85.72 \pm 17.38$ & $101.27 \pm 3.15$ & NS \\
\hline $\begin{array}{l}\text { High density lipoprotein } \\
(\mathrm{g} / \mathrm{dl})\end{array}$ & $21.22 \pm 6.49$ & $26.84 \pm 4.11$ & $28.22 \pm 11.24$ & $29.52 \pm 11.25$ & NS \\
\hline
\end{tabular}

$a, b$ means have different letter(s) in the same raw are significantly different $(P \leq 0.05)$

$N S$ : not significant

Table (7). Effect of feeding different dietary treatments on economic evaluation.

\begin{tabular}{lcccc}
\hline \multirow{2}{*}{ Items } & \multicolumn{4}{c}{ Dietary treatments } \\
\cline { 2 - 5 } & Control & $\mathrm{T}_{1}$ & $\mathrm{~T}_{2}$ & $\mathrm{~T}_{3}$ \\
\hline Live body weight gain (kg) & 1.982 & 2.135 & 2.035 & 1.982 \\
Price /kg body weight (LE) & 13 & 13 & 13 & 13 \\
Total revenue / chick (LE) & 25.766 & 27.755 & 26.455 & 25.766 \\
Total feed intake /chick (kg) & 3.253 & 3.283 & 3.123 & 3.595 \\
Total feed cost/chick (LE) & 11.939 & 12.148 & 11.604 & 13.429 \\
Fixed cost/chick (LE) & 8 & 8 & 8 & 8 \\
Total cost/chick (LE) & 19.939 & 20.148 & 19.604 & 21.429 \\
Net revenue (LE) & 5.827 & 7.607 & 6.851 & 4.337 \\
Economic efficiency (EE) & 22.6 & 27.4 & 25.9 & 16.8 \\
Relative (EE)\% & 100 & 121 & 115 & 74.3 \\
\hline
\end{tabular}

Total revenue/chick = Body weight gain $x$ price of one kl body weight $(13$ LE)

Total feed cost/chick = Total feed intake $x$ price of one $\mathrm{kg}$ feed (starter plus grower) during April 2013

Fixed cost $/$ Chick = Labor, medication and Vaccination, Electricity, Water, Care ... etc. $=8$ LE

Total cost $/$ chick $=$ Cost of feeding + fixed cost

Net revenue $=$ Difference between total revenue and total cost

Economic efficiency $($ EE) $=$ Netrevenue $/$ total cost $x 100$ 


\section{El-Faham et al.}

\section{REFERENCES}

Ali, M.A. (1999). Effect of probiotics addition to broiler rations on performance and some blood constituents. Egypt. Poult. Sci., 19: 161-177.

Abd El-Hady, Abd El-Rahman Y.M. (2012). Effect of enzyme proparationsaon apparent metabolizable energy of broiler diets. M.Sc. Thesis, Faculty of Agric., Ain Shams Univ., Egypt.

Abd El-Latif, S.A.; F.A. Ahmed A.M. El-Kaiaty (2002). Effect of feeding dietary thyme, black cumin, dianthus and fennel on productive and some metabolic responses of growing Japanese quail. Eygpt. Poultr. Sci., 22:109-125.

Abdel-Azeem, F.; A. Ibrahim; A. Faten and G.M. Ali, Nematallah, (2001). Growth performance and some blood parameters of growing Japanese quail as influenced by dietary different protein levels and microbial probiotics supplementation. Egypt. Poult. Sci., 21(11):465-489.

Adeola, O. and M.R. Bedford (2004). Exogenous dietary xylanase ameliorates viscosity - induced antinutrientional effects in wheat - based diet for white pekin ducks. Br. J. Nutr., 92:87-94.

Al-Khadri, A.M.A. (2013). Effect of ginger (Zingiberofficinale) and thyme (Thymus vulgaris) dietary supplementation on productive and immunological performance of broiler. M.Sc. Fac. of Agric. And Forestry School of Anim. Prod. Kurdistan Reg. Gover Iraq thesis.

Alvarega, R.R.; M.G. Zangeronimo, L.J. Pereira, P.B. Rodrigues and E.M. Gomide (2011). Lipoprotein metabolism in poultry. World's Poult. Sci. J., 67:431-440.

Café', M.B.; C.A. Borges; C.A. Fritts and P.W. Waldroup (2002). Avizyme improves performance of broilers fed corn-soybean meal-based diets. Journal of Applied Poultry Research, 11:29-33.

Dhama, K. and S.D. Singh (2010). Probiotics improving poultry health and production. An overview. Poult. Punch, 26:41-41.

Dhama, K.; V. Verma; P.M. Sawant; R. Tiwari; R.K. Vaid and R.S. Singh (2011). Applications of probiotics in poultry: Enhancing immunity and beneficial effects on production performances and health: A review. J. Immunol. Immunopathol., 13:1-19.

Dhama, K.; M. Mahendran and S. Tomar (2007). Probiotics and prebiotics: A safer way towards improving health and productivity in poultry. Poult. World., 2:28-32.

Dhama, K.; M. Mahendran; S. Tomar and R.S. Chauhan (2008). Beneficial effects of probiotics and prebiotics in livestock and poultry: The current perspectives. IntasPolivet, 9:1-12.

Dibner, J.J. and J.D. Richards (2005). Antibiotic growth promoters in agriculture: History and mode of action. Poult. Sci., 84:634-643.

Dorman, H.J.D. and S.G. Deans (2000). Antimicrobial agents from plants: antimicrobial activity of plant volatile oils. J. of Applied Micr., 88:308-316.

Duncan, D.B. (1955). Multiple ranges and multiple tests. Biometric, 11: 14.

El-Faham, A.I.; A.M. Ahmed and M.H.S. El-Sanhoury (2015). Thyme leaves or its extracted oil for enhancing productive and physiological status of broiler chickens. Egypt. Poult. Sci., 35:215-236.

El-Faham, A.I.; Nematallah, G.M. Ali and Hayam M.A.A. El-Maaty (2014). Effect of using some natural feed additives to substitute antibiotic growth promoters on performance and blood parameters of broilers. Egypt. Poult. Sci., 34:735-750.

European Commission (2003). Regulation of the European parliament and the council of 22 September 2003 on additives for use in animal nutrition official J. of European union, 268:29-43.

Furuse, M. and Yokota H. (1984). Protein and energy utilization in germ free and conventional chicks given diets containing different levels of dietary protein. Br. J. Nutr., 51:255-264.

Furuse, M.; S.I. Yang; N. Niwa and J. Okumura (1991). Effect of short chain fatty acids on the performance and the intestinal weight in germ free and conventional chicks. Br. Poult. Sci., 32:159165.

Ghazalah A.A. and Ali (2008). Rosemary leaves as a dietary supplement for growth in broiler chickens. Inter. of Poult. Sci., 7:234-239.

Ghazalah, A.A. and F.A. Ibrahim (1996). The possibility of using some edible and aromatic oils in the nutrition of Muscovi ducks. Egypt. Poult. Sci., 16:305-328.

Hassan, H.M.A.; M.A. Mohamed; A.W. Youssef and E.R. Hassan (2010). Effect of using organic acid to substitute antibiotic growth promoters on performance and intestinal microflora of broilers. AsianAust. J. Anim. Sci., 23:1348-1353.

Hassan, I.I.; A.A. Ashar and G.A. El-Shouragy (2004). Influence of some medicinal plants on performance; physiological and quality traits of broiler chicks. Egypt. Poult. Sci.,:247-266. 
Hassanein, H.H. (2006). Effect of dietary Alpha Yea Mix supplementation on boiler chickens performance. Egypt Poult. Sci., 26:1285-1303.

Hermier, D.C. (1997). Lipoprotein metabolism and fattening in Poultry. J. Nutr., 127:805-808.

Hillman, K. (1999). Manipulation of the intestinal microflora for improved health and growth in pigs. Proceedings of the WPSA spring Meteting, Scarborough, 22-24 March, pp. 59-61.

Hong, D.; D. Ragland and O.Adeola (2002). Additivity and associative effects of metabolizable energy and amino acid digestibility of corn, soybean meal and wheat on white pekin ducks. J. Anim. Sci., 80:3222-3229.

Kalmendal, R. and R. Tauson (2012). Effects of a xylanase and protease, individually on in combination and anionophorecoccidiostat on performance, nutrient utilization and intestinal morphology in broiler chickens fed a wheat-soybean meal-based diet. Poult. Sci., 91:1387-1393.

Kocher, A.; M. Choct, G. Ross; J. Broz and T.K. Chung (2003). Effects of enzyme combinations on apparent metabolizable energy of corn-soybean meal based diets in broilers. J. Appl. Poult. Res., 12:275-283.

Lee, K.W.; H. Everts and A.C. Beynen (2004). Essential oils in broiler nutrition. Int. J. Poult. Sci., 3:738752.

Mahima, A. Rahal; R. Deb; S.K. Latheef and H.A. Samed (2012). Immunomodulatory and therapeutic potentials of herbal, traditional/ indigenous and ethnoveterinary medicines. Rak. J. Biol. Sci., 15:754774.

Mahima, A.M. Ingle, A.K. Verma, R. Tiwari and K. Karthik(2013).Immunomodulators in day to day life: A review. Pak. J. Biol Sci., 16:826-843.

Mohnl, M.Y.; B. Acosta Ojeda; Rodriguez Sanchez and S. Pasteiner (2007). Effect of symbiotic feed additive in comparison to antibiotic growth promoter on performance and health status of broilers. Poult. Sci., 86 (Suppl. 1), 217.

Muramatsu, T.; S. Nakima and J. Okumura (1994). Modification of energy metabolism by the presence of the gut microflora in the chicken. Br. J. Nutr., 71:709-717.

Nematallah, G.M. Ali; A.F. Abdel-Salam; G.M. El-Gendi; A.A. Radwan andHeba Allah E. Megahid (2015). Modulation of physiological and microbiological broiler state by some growth promoters. Egypt. Poult. Sci., 35:591-608.

Nematallah, G.M. Ali; El-Faham, A.I.; Inas, I. Ismail and Hegazy, Mona, H. (2014). Effect of some medicinal plant seeds or Biostrong as feed additive on growth performance and some metabolic changes in broiler chicks. $7^{\text {th }}$ int. Poult. Conf. AinSukhna - Red sea, Egypt.

NRC (1994). Nutrient Requierments of Poultry. $9^{\text {th }}$ Edn., National Academy Press, Washington, DC., USA., ISBN-13: 9780309048927, pp: 20-81.

Ragab, M.S.; R.A. Magda and G.S. Farahat (2012). Effect of Molkhyia or parsley feeding on carcass characteristics, glutathione peroxidase enzyme activity and meat quality of two broiler strains. Egypt. Poult. Sci., 30:353-389.

Rahimi, S.; Z.T. Zadeh; M.A.K. Torshizi, R. Omidbaigi and H. Rokno (2011). Effect of the three herbal extracts on growth performance, immune system, blood factors and intestinal selected bacterial population in broiler chickens. J. of Agric. Sci. and Tech., 13: 527-539.

Safaa, H.M. (2013). Influence of dietary enzyme prepared at Ensiling (Zadoß) from hatch to 42 days age on productivity, slaughter traits and blood constituents in broiler chickens. Inter. J. of Poult. Sci., 9:529-537.

Saleh, F.; M. Tahir; A. Ohtsuka and K. Hayashi (2005). A mixture of pure cellulose, hemicellulose and pectinase improves broiler performance. Br. Poult. Sci., 46: 602-606.

Salim, H.M.; H.K. Hang; N. Akter; D.W. Kim and J.H. Kim (2013). Supplementation of Direct-fed microbials as an alternative to antibiotic on growth performance, immune response, cecal microbial population and ileal morphology of broiler chickens. Poult. Sci., 92: 2084-2090.

Salter, D.N.; M.E. Coates and D. Hewitt (1974). The utilization of protein and excretion of uric acid in germ free and conventional chicks. Br. J. Nutr., 31:307-318.

SAS (2004). SAS procedure guide version 6, $12^{\text {th }}$ Ed. SAS institute Ine.,cary, NC, U.S.A.

Seedor, J.G.; H.A. Quarruccio and D.D. Thompson (1991). The biophosphorate alendronate (MK-217) inhibits bone loss due to ovariectomy in rats. Journal of bone and Mineral Research, 6: 339-550.

Senjya, C.; S.K. Verma; S.S. Trivedia; R. Verma; H.S. Vijayarti and S. Vyas (2012). Metal stress and antibiotic susceptibility profile of some bacterial and fungal strains. J. Pure Applied Microbiol., 6:1727-1734.

Steiner T. (2009). Phytogenics in animal nutrition concepts to optimize gut health and performance. Nottingham Univ., Press, Nottingham UK, [ISBN- 13: 978-1- 904761 -71-6].

Tolba, A.A.; H.M.M. Sabry and S.M.M. Abuzeed (2004b). Effect of microbial probiotics on performance of broiler chicks under normal or stress: 1-Lactobacillus or pedioccus. Egypt. Poult. Sci., 24:351-367. 


\title{
El-Faham et al.
}

Tolba, A.A.; H.M.M. Sabry and G.G. Medani (2004a). Effect of microbial probiotics on performance of broiler chicks under normal or heat stress conditions: 2-Bacteria concentration or yeast culture. Egypt. Poult. Sci., 24:333-349.

Tollba, A.A.H. and M.S.H. Hassan (2003). Using some natural additives to improve physiological and productive performance of broiler chicks under high temperature conditions. 2- Black cumuin (Nigella sativa) or garlic (Allium sativum). Egypt. Poult. Sci., 23:327-340.

Yokota, H. and M.E. Coates (1982). The uptake of nutrients from the small intestine of genetobiotic and conventional chicks. Br. J. Nutr., 14: 349- 356.

Yu, B.S.; T.Wu; C.C. Liv; R. Gautheir and P.W.S. Chiou (2007). Effects of enzyme inclusion in a cornsoybean diet on broiler performance. Anim. Feed Sci. Technol., 134: 283-294.

\section{الأداء الإتتاجى ومكونات بلازما الام لبدارى التسمين المغذاة على علائق مضاف إليها بعض الإضافات الطبيعية}

\author{
أحمد إبراهيم الفحام1 ونعمة الله جمال الدين محمد على1 و أمال محمد حسن2 \\ " قسم إنتاج الدواجن - كلية الزراعة - جامعة عين شعس- شبر الخيمة مصر. \\ "** قسم فسيولوجى الحيوان والدواجن - مركز بحوث الصحراء ـ المطرية ـ القاهرة مصر. \\ أجريت تجربة على بدارى التسمين (2-5 أسبوع فى العمر) لداسة تأثير بعض إضافات الأعلاف على الأداء الإنتاجى والعائد

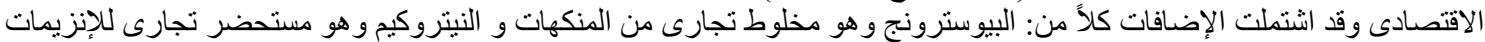 \\ و البيوجين وهو مستحضر تجارى سمبيوتلك الإنات \\ تم استخدام عدد (120) كتكوت هبرد هبرد عمر أسبوع ووز عت هذه الكتاكيت على 4 معاملات غذائية تجريبية لكل منها 30 كتكوت فى 3

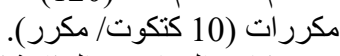 \\ وكانت المعاملات الغذائية كالآتى:

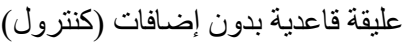 \\ عليقة قاعدية مضاف إليها 150 جم / طن بيوسترونج \\ عليقة قاعدية مضاف إليها 500 جم / طن النتروكيم (T)

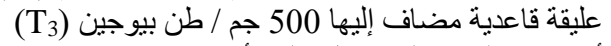 \\ أوضحت النتائج المتحصل عليهاف إليها أن: \\ 1- إضافة البيوسترونج (T) الو النتروكيم (T2) يعطى أعلى معدلات وزن جسم مكتسب (8 و 32\% على التو الى) بالمقارنة

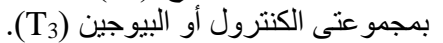

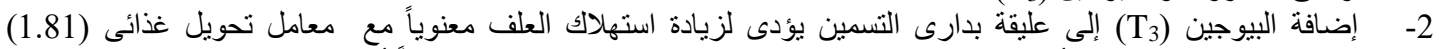

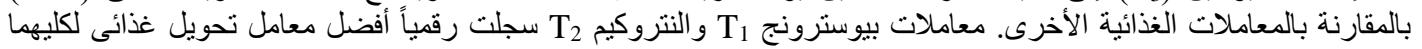 \\ (1.54) بينما معاملة الكنترول (1.65).

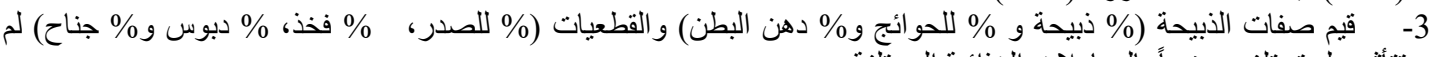 \\ تتأثر ولم تختلف معنوياً بالمعاملات الغذائية المختلفة. \\ 4- قيم صفات العظم (وزن وسمك عظمة الساق) لم تتأثر بالمعاملات المختلفة بينما (طول عظمة الساق و وSeedor Index) \\ تأثرت معنوياً بالمعاملات الغذائية المختلفة.

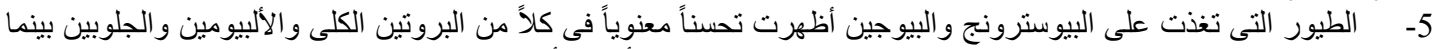

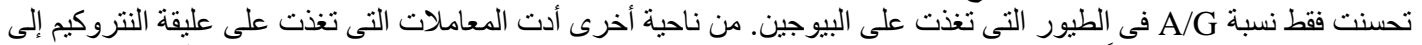

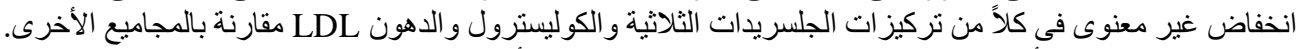

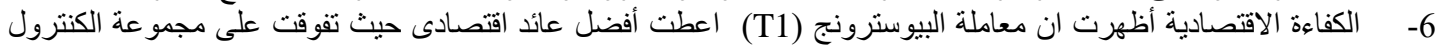

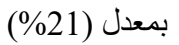 \\ الخلاصة: إضافة البيوسترونج بمعدل 150 جم/طن إلى علائق بدارى التسمين أدى إلى تحسن الأداء الإنتاجى والكفاءة الاقتصادية \\ لكتاكيت التسمين (سلالة الهبرد).
}

